\title{
How will anthropology cope with the challenges of a changing world?'
}

\author{
Ruben George Oliven ' \\ ' Programa de Pós-Graduação em Antropologia Social, Universidade Federal do Rio Grande do Sul, \\ Porto Alegre/RS, Brasil
}

\begin{abstract}
The world has gone through many changes since the beginning of Anthropology and during the current century we will see many other changes that are impossible to predict. This article discusses what sort of theories and methodologies Anthropology will have to develop in order to understand what is going on in the world today. One of the challenges of Anthropology will be both to remain committed to rights of the groups that represent cultural diversity and to the theoretical task of offering interpretations of the social phenomena with which the world is faced.
\end{abstract}

Key words: Challenges of Anthropology; $21^{\text {st }}$. Century; Social changes, Brazil.

\section{Como a antropologia vai lidar com os desafios de um mundo em transformação?}

\section{Resumo}

O mundo passou por muitas mudanças desde o início da Antropologia e durante o século atual veremos várias outras mudanças impossíveis de serem previstas. Este artigo discute que tipo de teorias e metodologias a Antropologia precisa desenvolver para entender o que está acontecendo com o mundo atualmente. Um dos desafios da Antropologia será simultaneamente se manter comprometida com os direitos dos grupos que representam a diversidade cultural e com a tarefa intelectual de oferecer interpretações dos fenômenos sociais com o qual o mundo se depara.

Palavras-chave: Desafios da Antropologia; Século XXI; Mudanças Sociais; Brasil.

\footnotetext{
$1 \quad$ Paper presented at the Symposium “Challenges and Perspectives of Anthropology in the $21^{\text {st }}$ Century" held at the $18^{\text {th }}$ World Congress of the International Union of Anthropological and Ethnological Sciences. Florianópolis, Brazil, July 18, 2018.
} 


\title{
How will anthropology cope with the challenges of a changing world?
}

\author{
Ruben George Oliven
}

I am aware of the risks entailed in the title I chose to give to this symposium. Imagine if in 1918 we asked Malinowski to give a paper about the challenges and perspectives of Anthropology in the $2 \mathrm{O}^{\text {th }}$ Century. World War I was just ending. No one could guess that barely 21 years later a new world war would ensue. The world was ravaged by a flu epidemic that killed more people than the war. There were no antibiotics. Colonialism still dominated the world, but the Soviet Revolution had just happened. How could anybody guess that during the rest of the century there would be heart transplants, computers, the Aids epidemic and so many other things that happened? And what about Anthropology? Think about the Anthropology Malinowski developed and the different trends that came after him like postmodern Anthropology, Feminist Anthropology, Anthropology of the Cyberspace, Perspectivism (Grimshaw \& Hart 1994; Borofsky 2019). How could anybody imagine this would take place?

Difficulties aside, the exercise of thinking about the future of our profession is still very relevant. And since I and most of the people who are attending this conference probably will not be alive at the end of the $21^{\text {st }}$ century, we can discuss this topic without too many fears.

I will of course not make any prophecy about how the world will be in the year 2100. But there are two points I want to stress as being cornerstones of Anthropology. The first has to do with the moral engagement and commitment of Anthropology towards the groups that have traditionally been excluded of what is called modernity but have suffered its consequences. The obligation we feel towards those groups has a moral dimension and is based on the idea of the richness of cultural diversity and the need to respect and preserve it (Narotsky 2016; Pickering 2017).

In this sense, Brazilian Anthropology is in a privileged position. Since its inception it has been committed with the native societies of the country and more recently with the maroons, the descendants of slave communities. A great part of the political work of the Brazilian Anthropological Association (ABA), one of the oldest Brazilian scientific societies, created in 1955 and one of the largest Anthropological Associations with over 1.000 members, has precisely to do with natives and maroons. During the military dictatorship, ABA did not shy away from defending them. When the military regime ended, ABA lobbied for the rights of natives during the drafting of our Constitution of 1988 and was able to help to secure $12,5 \%$ of Brazilian territory for them. In the same sense, the rights to land for communities descending from ex-slaves was also inscribed in our Constitution. Since then, ABA has fought in different arenas to ensure that the lands that belong by law to those two groups be assured and that they are given legal titles to them. ABA has signed an agreement with the Brazilian Prosecutor-General Office whereby we appoint one of our members as expert witness whenever there is a dispute about lands of those communities.

Unlike other countries, in Brazil it is difficult to make a distinction between academic and public intellectuals. If you are in the social sciences, mainly as an anthropologist you end up becoming a public intellectual because the challenges facing Brazil - such as social inequality, racial discrimination, gender inequalities, homophobia - are so big that you are drawn into the debates about those issues and ways of solving them (Lima, Beltrão, Lobo, Castilho, Lacerda \& Osório 2018). 
Originally, Anthropology was practiced mostly by white European men who studied natives in their colonies. Things are changing, and we are starting to have anthropologists who are natives. In this sense, all graduate programs of Brazilian public universities are having affirmative action measures and quotas for natives and African-Brazilians. That means that we will soon have natives that are anthropologists, thus broadening the anthropological perspective.

The second point I would like to stress has to do with the intellectual practice of Anthropology. Whatever the differences between the existing and the future schools and theories of Anthropology, our science has to do with interpreting social and cultural phenomena. Inasmuch Anthropology deals with very different societies, what we try to do is to understand what those phenomena mean for the groups that practice them and what is the logic beneath them. No matter how different anthropological theories can be, there is no way they can shy away of trying to explain cultural and social phenomena.

Formerly the others were called natives and they were not only geographical removed, but they were very different from the societies from where the anthropologists came from. Nowadays, the natives can be very close to us or can be ourselves. Still, we must explain why they or we do certain things and what is the logic of their behavior. In this sense what Malinowski wrote in Argonauts of the Western Pacific stills holds, when he stated that the goal of the anthropologist, or ethnographer, is: "to grasp the native's point of view, his relation to life, to realize his vision of his world" (Malinowski 1961: 25.)

Anthropology started with the study of the so-called primitive societies. That is what informed anthropological theories from its beginning. But nowadays, although anthropologist still do field work in simple societies, they tend increasingly to turn to their own societies. Can anthropology explain what is going on in the world today? What sort of theories and methodologies do we need to face the challenges that present themselves in the 21st century? (Koizumi 2016).

Anthropology has always given important contributions to the understanding of the world we live in. Through detailed ethnographic research it has shown how different ways of life and meanings can be. Nowadays, anthropologists study not only simple societies but also phenomena that are happening in more complex societies (Ingold 2014). Thus, we have anthropological studies of the stock market, the cyberspace, communities living in megalopolis, etc. Although anthropologists tend to carry out detailed studies of specific phenomena, they do not shy away from offering broader interpretations of what is happening with the world at large. Anthropologists do not just look at the microprocess of phenomena but also the macro perspective and its implications (Ribeiro 2014).

We are currently experiencing a century that is changing in an unprecedented speed. Just to name some of the changes we are facing: new technologies, vast migrations from one continent to the other, revival of nationalism combined with global processes. It is difficult to forecast what will happen in the next 82 years, but it is important to discuss the challenges and perspectives Anthropology will face in the rest of the $21^{\text {st }}$ century.

Traditionally anthropological theory has been produced in the global North. Anthropologists from the global South are now starting to develop their own theories. This has already begun in the study of natives with the development of Perspectivism (Viveiros de Castro 2012, Ramos 2012). But I would like to argue that in order to explain what is going on in the world today we need more voices from the South. I am thinking particularly about migration, ethnicity and the rise of populism and conservatism. During a long period of time we heard theories that emphasized how globalization was homogenizing cultures. Without denying that there are products of mass culture that can be found everywhere, what we actually see is the return of the repressed, namely localism. This can be found in a healthy way with the revival of traditions and local cultures. But it can also be found in conservative waves, in the return of ethnic conflicts (remember the dismembering of Yugoslavia in the heart of Europe), in reactions to immigrants in Europe and the United States, and in Brexit, etc. 
Migration is perhaps one of the crucial questions of the $21^{\text {st }}$ Century. People from poorer countries or of countries fraught with conflicts are trying to settle in richer countries where they have more opportunities. Those countries need the immigrants to perform activities that the local population is not willing to engage in. Think for example about the agriculture of California, one of the richest of the world. It would not be feasible without the labor of the undocumented Mexican workers. But although countries like the United States were formed by immigrants, these are no longer welcome.

Ethnicity plays a central role in this type of situation. A conservative wave is taking place in different countries. It is based on the dislike for the unlike and is frequently promoted by populist politicians who paint the other as dangerous and threatening to the purity of the nation. It exploits the fear of those who have lost with economic changes brought about by globalization. It is relatively easy to convince unemployed people to blame the immigrants for the loss of their jobs. We have seen similar things in other periods of history.

The fact is however that the ethnic composition of central countries is rapidly changing. In the same sense as the United States is no longer demographically WASP due to the influx of immigrants, many countries in Europe are becoming less white and Christian. This brings about a series of issues about which Anthropology is well equipped to interpret.

Similar things can be said about countries like Brazil (Souza Lima 2016, Simião \& Feldman-Bianco 2018). If for a long time, Brazil saw itself and was seen as a mestizo nation where racial democracy prevailed, today there is a growing awareness that this is not so. In fact, many people now speak about what is called "cordial racism," which begins with the cultural difficulty of acknowledging that Brazil has prejudice, discrimination, and racial inequality. This is clear in official statistics that show that blacks are worse off on any social indicator, including education, income, literacy, infantile mortality, and life expectancy. Traditionally social scientists and the population in general believed that Brazilian nonwhites were worse off because they were part of the poorer sectors of the population. Recent data and interpretations show that in fact they are doubly discriminated against: for being poor and for being black.

Our last census has shown that demographically whites no longer are the majority of the population, although they dominate society. A similar trend is happening with religion. Brazil has always been a country of deeply rooted religiosity, traditionally Catholic, albeit with very particular and popular forms of that religion. Although Brazil still is the largest Catholic country in the world, the panorama is quickly changing with the growth of Pentecostalism and Afro-Brazilian religions. Pentecostalism has grown at an impressive speed and is now the second-largest religion in Brazil. It is not only a religious enterprise but also a political and economic one. Many pastors have been elected to Congress, where they form a group that votes together whenever a religious issue is at stake (abortion, religious education, etc.). The Universal Church of the Kingdom of God, established in Brazil in 1977, has churches in approximately 120 other countries, including North America and the European Union, mobilizing millions of faithful followers and large sums of money. Its founder is the owner Brazil's second-largest television network.

During the rest of the $21^{\text {st }}$ Century we will certainly see many other changes that are impossible to predict now. The challenge of Anthropology will be both to remain committed to rights of the groups that represent cultural diversity and to the theoretical task of offering interpretations of the social phenomena the world is faced with.

Received: June 27, 2019

Approved: July 03, 2019

Translated by David Rodgers 


\section{Bibliography}

BOROFSKY, Robert. 2019. “An Anthropology of Anthropology”. Kailua, HI, Center for a Public Anthropology. Mimeo.

GRIMSHAW, Anna; HART, Keith. 1994. "Anthropology and the Crisis of Intellectuals". Critique of Anthropology, 14(3): 227-261.

INGOLD, Tim. 2014. "That's enough about ethnography”. Hau:Journal of Ethnographic Theory, 4(1): 383-395. KOIZUMI, Junji. 2016. “Global Anthropology versus Anthropologies”. American Anthropologist, 118(4): 857858.

MALINOWSKI, Bronislaw. 1961. Argonauts of the Western Pacific. New York: Dutton.

NAROTSKY, Susana. 2016. “Anthropology and Anthropologies in Tension”. American Anthropologist, 118(4): $843-845$.

PICKERING, Andrew. 2017. “The Ontological Turn. Taking Different Worlds Seriously”. Social Analysis, 61(2): 134-150.

RAMOS, Alcida Rita. 2012. "The Politics of Perspectivism”. Annual Review of Anthropology, 41: 481-494.

RIBEIRO, Gustavo Lins. 2014. "World Anthropologies: Anthropological Cosmopolitanisms and Cosmopolitics. Annual Review of Anthropology, 43: 483-498.

SIMIÃO, Daniel Schroeter; FELDMAN-BIANCO, Bela (orgs.). 2018. O campo da antropologia no Brasil: retrospectiva, alcances e desafios. Rio de Janeiro: Associação Brasileira de Antropologia.

SOUZA LIMA, Antonio Carlos de. 2016. "On the Construction of (a) World Anthropology(ies): A View from Brazil”. American Anthropologist, 118(4): 851-855. .; BELTRÃO, Jane Felipe; LOBO, Andrea; CASTILHO, Sergio; LACERDA, Paula; OSÓRIO, Patrícia (orgs). 2018. A Antropologia e a Esfera Pública no Brasil. Rio de Janeiro. Rio de janeiro: ABA.

VIVEIROS DE CASTRO, Eduardo. 2012. "Cosmological perspectivism in Amazonia and elsewhere". Hau Journal of Ethnographic Theory (Masterclass Series vol. 1), 1: 45-168.

\section{Ruben George Oliven}

Postgraduate Programme in Social Anthropology, Federal University of Rio Grande do Sul, Research Fellow of the National Council for Scientific and Technological Development. https://orcid.org/oooo-0003-3556-6955

Email: ruben.oliven@gmail.com 